\title{
Mucosal delivery systems of antihypertensive drugs: A practical approach in general practice
}

\author{
Lukasz P. Bialya, , Cezary Wojcikc, Izabela Mlynarczuk-Bialy ${ }^{\mathrm{a}, \mathrm{b}}$
}

Patients who are unable to receive oral medication (p.o.) are a major problem in outpatient settings, especially in home health care systems. Mucosal administration of drugs offers an alternative to the oral route, especially when the parenteral mode cannot be used. There are three main pathways of mucosal administration: sublingual/buccal, intranasal and rectal. We discuss the possibility of mucosal delivery of antihypertensive drugs. Perindopril arginine and Amlodipine besylate are registered in the EU as orodispersible tablets for oromucosal delivery, however, they are not available in all countries. For this reason, we describe other drugs suitable for mucosal delivery: Captopril and Nitrendipine in the sublingual system and Metoprolol tartrate, Propranolol and Furosemide by the transrectal route. Based on the published data and common clinical practice we discuss the use of mucosal delivery systems of all these antihypertensive drugs with special attention to their pharmacokinetics. We illustrate this mini-review with a case report of the prolonged-term use of mucosal delivery of sublingual Captopril and Nitrendipine combined with rectal Metoprolol tartrate and Furosemide in a patient with severe hypertension unable to receive medication p.o. This is also a report on the first human use of Furosemide-containing suppositories as well as prolonged-term transmucosal administration of these four drugs, describing a practical approach leading to successful control of severe hypertension with four antihypertensive drugs delivered via the mucosal route. The treatment was effective and without side effects; however, the long-term safety and efficacy of such therapy must be confirmed by randomized clinical trials.

Key words: antihypertensive drugs, mucosal drug delivery, metoprolol, furosemide, suppositories

Received: October 26, 2017; Accepted with revision: April 16, 2018; Available online: May 15, 2018

https://doi.org/10.5507/bp.2018.022

aPrivate General Practice (Praktyka Lekarska dr n. med. Lukasz Bialy), Warsaw, Poland

${ }^{b}$ Department of Histology and Embryology, Medical University of Warsaw, Warsaw, Poland

'Department of Family Medicine, Oregon Health and Sciences University, Portland, OR, USA

Corresponding author: Lukasz Bialy, e-mail: Ibialy@esculap.pl

\section{CLINICAL PROBLEM}

Patients who are unable to tolerate oral medications (a.k.a. p.o.) create a major problem in general practice, esp. in home health care system. Parenteral therapy is problematic for General Practitioners and home health nurses. It is normally not available for long-term home therapy in Poland. In some countries, parenteral administration of drugs is part of the Hospital in the Home (HiTH) programs coordinated by inpatient centers, but not by outpatient general practice, esp. in Outpatient Parenteral Antimicrobial Therapy (OPAT) programs, which focus on short-term administration of antibiotics ${ }^{1}$. Mucosal administration systems offer an alternative to p.o. or parenteral (i.v. or i.m.) routes. They can be easily used for self-administration of drugs ${ }^{2}$. Another alternative is the transdermal system. Clonidine patches are commonly used in the US, but they are not available in the EU.

\section{MUCOSAL ADMINISTRATION ROUTE}

There are three main pathways of mucosal administration: sublingual/buccal (a.k.a. s.l.), rectal (a.k.a. p.r.) and nasal. The mucosal route is commonly used if rapid action of a drug is required and the parenteral administration cannot be used or is not acceptable $\mathrm{e}^{3,4}$. The substances absorbed from oral, nasal or rectal mucosa bypass liver first-pass metabolism. Therefore, ideal drugs for mucosal route should be given in their active form (not pro-drugs). In the case of drugs undergoing extensive hepatic inactivation, their action is more potent in comparison to p.o. administration ${ }^{5}$. The mucin present in saliva increases drug absorption from the oral cavity ${ }^{6}$.

Drugs for transmucosal absorption in the oral cavity can be given in the form of tablets, lozenges, films, sprays, gels, patches etc. Orally disintegrating tablets (a.k.a. ODT) also called orodispersible tablets are specially designed for drug delivery through the oral mucosa. ODT are mouth dissolvable, rapidly disintegrating tablets. These are prepared by addition of super-disintegrants i.e. crosspovidone, crosscarmellose sodium, sodium alginate, acrylic acid derivatives ${ }^{7,8}$. The European Pharmacopoeia has used the term orodispersible tablet for tablets that disperse readily within 3 minutes in the mouth before swallowing ${ }^{9}$. In the US, the FDA has defined ODT as "A solid dosage form containing a medicinal substance or active ingredient which disintegrates rapidly usually within a matter of seconds when placed upon the tongue" $\left(\right.$ ref. $\left.{ }^{10}\right)$. The disintegration time for ODTs generally ranges from several seconds to about a minute ${ }^{9}$. 
Perindopril arginine and Amlodipine besylate are registered in the EU in the form of orodispersible tablets for oromucosal delivery. However, they are not available in all EU countries. Sublingual clonidine sublingual tablets are available in the US. Currently there are no special oral mucosal forms of any hypertensive drug available in Poland. In the case of the ACE inhibitor Captopril, one of most widely used hypertensive drugs, normal p.o. tablets are used for sublingual administration in hypertensive urgencies. Such administration guarantees faster drug action. However, $1 \mathrm{~h}$ after administration the antihypertensive activity of sublingual Captopril is comparable to that for tablets which have been swallowed immediately ${ }^{11}$.

The intra nasal route has been used for the delivery of several drugs ${ }^{12}$. However, there is only one report on the possibility of antihypertensive drug (timolol) administration via this route ${ }^{13}$.

The rectal route does not require significant patient cooperation creating a big advantage in special cases, e.g. if patients are unconscious or vomiting, as well as in the elderly, delirious or pediatric patients, when they refuse to receive p.o. drugs ${ }^{14-16}$. Suppositories are the most common form of trans-rectal drug delivery. There are three main types of bases used to make suppositories: hydrophobic (e.g. Cacao Butter, Adeps Solidus [Witepsol]); amphipathic (e.g. Suppocire AP), or water soluble/emulsions (e.g. PEG-s/glycerol) (ref. ${ }^{17}$ ). In compounding pharmacies, Cacao Butter is most often used to prepare suppositories. Drugs administered per rectum also avoid liver first-passage effect but they absorption from commonly used suppositories is longer than from special sublingual tablets ${ }^{18}$. Moreover, vagina can be considered also as a potential route for systemic drug delivery in women ${ }^{19,20}$.

\section{SELECTED ANTI-HYPERTENSIVE DRUGS FOR MUCOSAL ADMINISTRATION}

According to ESC/EHC guidelines several drug categories are recommended for antihypertensive therapy including angiotensin-converting enzyme inhibitors and angiotensin receptor blockers, calcium channel-blockers, beta-blockers, diuretics, renin-antagonists, alpha-adrenergic agonists and other central acting drugs ${ }^{21}$. Here we will discuss selected drugs from the main groups of antihypertensive agents in the context of their mucosal (s.1. and p.r.) delivery.

\section{Perindopril}

Perindopril is a nonsulfhydryl prodrug ester of perindoprilat. There are two types of esters available: Perindopril erbumine and Perindopril arginine. Perindopril arginine is $\sim 30 \%$ more stable in tablets than erbumine ester resulting in increased experience time for use of tablets to 2-3 years ${ }^{22,23}$. Both of them requite liver metabolism for activation and display first pass effect (62\%) and systemic hydrolysis (38\%) to perindoprilat after administration p.o. $\left(\right.$ ref. $\left.{ }^{24}\right)$. The half time of Perindopril is $1.2 \mathrm{~h}$, however, its active metabolite peridoprilat has a much more longer reaching 30-120 $\mathrm{h}$ thus the antihypertonic effect of
Perindopril is more then $24 \mathrm{~h}$ (ref. ${ }^{24}$ ). Use of Perindopril is well established in the treatment of patients with hypertension or heart failure and it has been used in clinical practice from several years ${ }^{25-29}$.

Perindopril arginine is registered in some EU countries in the form of orodispersible tablets ${ }^{30}$. However it is not commercially available in Poland. Pharmacological properties of ODT Perindopril arginine are the same as conventional tablets. However, Perindopril is a prodrug and needs liver metabolism for its activation to perindoprilat the peak plasma concentration of perindoprilat is achieved within 3 to 4 after s.l. administration of the ODT $\left(\right.$ ref. ${ }^{31}$ ). The antihypertensive effect of Perindopril arginine in after ODT delivery is exactly the same as the classic arginine Perindopril tablet, hence they can be administered once a day ${ }^{30,31}$.

The effectiveness and compliance of Perindopril arginine ODT was assessed in the OPTIMUM program ${ }^{32}$. In this post-marketing open observational study the patients with $1^{\text {st }}$ and $2^{\text {nd }}$ degree hypertension were included and observed for 6 months. The mean duration of disease was 7.0+/-6.2 years (median 5 years). During the observation $91.4 \%$ of patients reached target BP $(<140 / 90 \mathrm{~mm} \mathrm{Hg})$ after 3 months of treatment. Adherence to the treatment improved significantly and patients declared that ODT form dissolves quickly and is easy to use at home or traveling.

\section{Captopril}

Captopril is a sulfhydryl inhibitor of angiotensin-converting enzyme (ACE-I). It is an active compound (not a pro-drug) and in contrast to almost all ACE-I (with exception of Lisinopril) it does not requite liver metabolism for its activation ${ }^{24}$. Thus it is active directly after sublingual mucosal absorption. It is a short-lived drug (half-life of approximately $2 \mathrm{~h}$ ) therefore requires TID administration ${ }^{33}$. In hypertensive urgencies oral tablets Captopril are most widely used sublingually, enabling faster antihypertensive effect.

\section{Nitrendipine}

Nitrendipine is a dihydropyridine calcium channel blocker with a terminal half-life time of $8 \mathrm{~h}$. Usually it is administered BID (ref. ${ }^{24}$ ). It is inactivated in liver displaying "first pass" effect after p.o. administration ${ }^{34}$.

Sublingual mucosal administration of both Captopril and Nitrendipine is a well-accepted strategy in the treatment of hypertensive urgencies ${ }^{35}$. In these case, the most common is sublingual Captopril administration ${ }^{36,37}$. Sublingual Captopril acts faster within first $30 \mathrm{~min}$, however, there are no differences in blood pressure reduction $1 \mathrm{~h}$ after drug delivery in comparison to the conventional p.o. route .11,38. $^{1}$.

The sublingual mucosal route of Nitrendipine administration enables also fast and effective blood pressure reduction during first $45 \mathrm{~min}$ and lasting at least $8 \mathrm{~h}$ (ref. ${ }^{39,40}$ ). This route of Nitrendipine administration is safe and does not cause hypotension even combined with PDE-V inhibitor tildenafil ${ }^{41}$. However, when Nitrendipine is administered s.l. in the form of normal oral tablets 
(available in Poland) it displays slower anti-hypertensive activity than the same tablets taken p.o. $\left(\right.$ ref. $\left.^{42}\right)$.

\section{Amlodipine}

Amlodipine is a third-generation dihydropyridine calcium channel blocker with very slow rate of elimination (half-life time of 40-60 h) thus it is administered once a day ${ }^{43}$. It is slowly but almost completely absorbed from the gastrointestinal tract with oral bioavailability $\sim 60-90 \%$ (ref. ${ }^{24}$ ). The peak plasma concentrations are reached 4-8 h following p.o. administration. It is inactivated in liver displaying slow but extensive (90\%) hepatic biodegradation to inactive metabolites after p.o. administration ${ }^{44}$.

The position of Amlodipine in the treatment of hypertension and coronary heart disease is well established by several clinical trials and meta-analyse ${ }^{27,45-49}$ )

Amlodipine can be also produced in the form of various orodispersible tablets ${ }^{50-52}$. In this form Amlodipine is registered in some EU countries for transmucosal administration ${ }^{53}$. However it is not commercially available in Poland. The ODT form of Amlodipine besylate is comparatively bioequivalent to conventional tablets ${ }^{54,55}$. ODT Amlodipine was successfully tested in geriatric patients ${ }^{56}$. The main drawback of using ODT Amlodipine is its bitter taste ${ }^{57}$.

\section{Metoprolol}

Metoprolol is a selective $\beta 1$ receptor blocker without intrinsic sympathomimetic activity that is administered BID in the form of tartrate due to its short half-life 3-4 $\mathrm{h}\left(\right.$ ref. $\left.^{24}\right)$. In contrast, Metoprolol succinate has a much longer half-life allowing for once daily administration ${ }^{24}$. Metoprolol is lipophilic and undergoes enzymatic inactivation in the liver displaying an extensive first-pass metabolism reducing its bioavailability $\sim 40 \%$ after p.o. administration ${ }^{58,59}$. Rectal administration of Metoprolol tartrate has been tested both in human an in animal models ${ }^{60,61}$. In healthy volunteers, rectal bioavailability of Metoprolol tartrate of Adeps Solidus (Witepsol)-based suppositories was comparable to that for p.o. route. Metoprolol was absorbed quickly from rectum with AUC higher than those after p.o. administration; however, this difference was not statistically significant ${ }^{61}$. In animal model the use of emulsion suppository base significantly increased the AUC (1.88-fold) as compared to the oral tablets $^{60}$. The same authors reported the highest in vitro Metoprolol release for emulsion suppository bases (40-80\% after $120 \mathrm{~min}$ ) and the lower for amphipathic Suppocire AM (45\% after $120 \mathrm{~min}$ ) and lipid-based (15$30 \%$ after $120 \mathrm{~min}$ ). Among all lipid bases the lowest drug release was observed from Cacao Butter (about 5\% after $120 \mathrm{~min})$. The emulsion based Metoprolol tartrate suppositories reduced BP significantly faster while the effect of lipid-based suppositories was delayed (1.5-4 $\mathrm{h}$ after single dose p.r. dose). However, all types of Metoprolol tartrate suppositories strongly decreased heart rate in this mode ${ }^{60}$. Moreover, Adeps soludus-based suppositories containing $25 \mathrm{mg}$ of Metoprolol tartrate reduced effectively heart rate (19\%), systolic BP (14\%) and diastolic BP
(15\%) also in humans $8 \mathrm{~h}$ after medication ${ }^{61}$. Thus, due to the liver by-pass after p.r. administration and higher bioavailability of Metoprolol tartrate, it is administered in slower-releasing suppository bases for obtaining heart rate and $\mathrm{BP}$ reduction without severe side effects.

\section{Propranolol}

Propranolol is a highly lipophilic drug nonselective beta-blocker without intrinsic sympathomimetic activity. It is administered BID or TID due to its short half-life (3-4 h) time, however the main metabolite 4-hydroxypropranolol has a longer half-life (5.2-7.5 h) (ref. $\left.{ }^{24,62,63}\right)$. Propranolol displays extensive and unpredictable firstpass liver metabolism (75-85\%) when administered p.o. reducing its bioavailability to $26 \%$ because it is metabolized by the liver before it can reach the circulation when taken orally ${ }^{64}$. Propranolol is almost completely absorbed from the GI tract; however, plasma concentrations attained are quite variable among individuals ${ }^{24}$. It was reported to be appropriate for buccal mucoadhesive tablets ${ }^{65}$. Rectal administration of Propranolol has been tested both in animals ${ }^{66-69}$ and in humans ${ }^{70-72}$. In healthy volunteers, rectal bioavailability of Propranolol is better than for administration p.o. An approximately two-fold higher plasma Propranolol concentration was observed after rectal administration as compared with oral dosing due to omitting liver by pass effect. AUC indicate a significantly higher bioavailability of Propranolol administered by the rectal route $^{70,71}$. In clinical use, rectal Propranolol was reported to be effective in a case report of paroxysmal sympathetic hyperactivity in critically ill 15 -year-old Caucasian male with altered gastrointestinal tract. Because oral intake was contraindicated he was successful administered Propranolol $40 \mathrm{mg}$ per rectum every $6 \mathrm{~h}$ for symptomatic control $^{72}$. Rectal suppositories based on highly hydrophobic bases i.e. stearic acid or bees wax are slow releasing but relative bioavailability of Propranolol from these bases is good about 83 to $87 \%$ and beta-blockade lasts during 1-9 h post administration up to about $40-50 \%$ in rabbits ${ }^{67}$. The tempo of absorption form suppositories can be increased by addition of disintegrants i.e. microcrystalline cellulose thus rapidly reaching high serum concentration corresponding to more than $95 \% \beta$-blockade, while absorption and bioavailability are more than 3 fold increased in comparison to p.o. administration ${ }^{68}$. Moreover addition of cremophores i.e. lauric acid increases Propranolol absorption rate from Witepsol base ${ }^{69}$, hence dispersion of Propranolol in microspheres within suppositories results in sustained release of the $\operatorname{drug}^{73}$.

\section{Furosemide}

Furosemide is a commonly used loop diuretic inhibiting the $\mathrm{Na}+/ \mathrm{K}+/ 2 \mathrm{Cl}$ - cotransporter in the thick ascending limb of the loop of Henle with short terminal half-life of approximately $2 \mathrm{~h}\left(\right.$ ref. $\left.^{24}\right)$. As it is a weak acid soluble in organic solvents Furosemide is not absorbed completely from the GI tract after p.o. administration ${ }^{74,75}$. Moreover, Furosemide displays a first pass effect by undergoing enzymatic deactivation in liver ${ }^{76,77}$. Thus, its p.o. bioavailability is $50 \%$ lower than after parenteral administration ${ }^{24}$. 
The sublingual route of Furosemide has been tested in humans for pharmacokinetic studies and sublingual administration offers higher bioavailability and a stronger initial diuretic response than oral ${ }^{78}$. However, in the published literature there are no reports of p.r. Furosemide administration in humans. However, it has been reported that Furosemide can be administered in the form of p.r. suppositories in rats ${ }^{79-81}$. After p.r. administration the highest Furosemide release was observed from amphipatic suppository bases (i.e. Suppocire) or after addition of non-ionic surfactants (i.e. Solutol HS 15, Cremophor RH 60, Montanox 60 DF) to lipophilic bases. However a diuretic effect of Furosemide released from Lipophilic base (Witepsol H 15) was comparable to that after oral $\operatorname{administration}^{79}$.

\section{PRACTICAL APPROACH}

To illustrate the use of mucosal route for the delivery of multiple antihypertensive drugs in general practice settings, we describe a case of a 60-y old hypertensive woman complaining of postprandial emesis. Her past history is significant for partial gastrectomy modo Billroth II several years ago due to peptic ulcer disease, complicated by severe gastric stenosis with debris retention within gastric stump confirmed by EGD, malabsorbtion syndrome (BMI $17.4 \mathrm{~kg} / \mathrm{m}^{2}$ ), and microcytic anemia. At the first visit to a new Family Physician (GP/FP) she complained of severe vomiting lasting since 3 days, making p.o. drug administration ineffective. Her blood pressure was 220/120 $\mathrm{mmHg}$ and heart rate was $110 / \mathrm{min}$. ECG revealed sinus tachycardia with features of left ventricle hypertrophy
$(\mathrm{Sv} 1+\mathrm{Rv} 5 / 6>35 \mathrm{~mm})$. She denied chest pain or shortness of breath. Patient refused the recommendation to be transported to regional hospital emergency unit.

Sublingual administration of Captopril $25 \mathrm{mg}$ in the outpatient clinic reduced BP to 200/105 $\mathrm{mmHg}$ within $45 \mathrm{~min}$. No further BP reduction was observed within next $30 \mathrm{~min}$. After s.1. administration of a second dose of Captopril (25 mg) with Nitrendipine (10 mg) BP fell to $185 / 100$ within next $60 \mathrm{~min}$. BP reduction to $160 / 80$ was achieved 60 min after administration of a second dose of s.l. Nitrendipine (10 mg) combined with $20 \mathrm{mg}$ of Furosemide i.m. At that point patient was released home.

In the following weeks this patient received an oral combination of more than three hypertensive drugs incl. diuretics and beta-blockers in maximal registered doses without satisfactory control of blood pressure. She was still having nausea and vomiting at least 1 time daily. Her blood pressure measured in outpatient clinic was within the range $180 / 90 \mathrm{mmHg}$ to $190 / 100 \mathrm{mmHg}$.

Finally, she was started on sublingual regimen of Captopril $50 \mathrm{mg}$ TID and Nitrendipine $10 \mathrm{mg}$ BID. On this medication regimen, her BP measured in office ranged from $170 / 85$ to $175 / 90 \mathrm{mmHg}$ with persistent tachycardia HR 100-120/min.

After analysis of the published literature a specific medical management protocol was developed by the medical team in order to achieve her BP goals. She has been advised to initiate in addition to her sublingual regimen an additional, unorthodox therapy through rectal administration of Metoprolol tartrate and Furosemide suppositories. The patient agreed to such therapy.

Pharmaceutical laws in Poland allow administration of compounded medications made from approved drugs,

Table 1. Armamentarium of antihypertensive drugs used for mucosal delivery.

\begin{tabular}{|c|c|c|c|c|c|c|c|}
\hline Name & Group & $\begin{array}{l}\text { Mucosal } \\
\text { route }\end{array}$ & Pro-drug & $\begin{array}{l}\text { Liver } \\
\text { metabolism }\end{array}$ & $\begin{array}{l}\text { Half-life time } \\
(\mathrm{h})\end{array}$ & $\begin{array}{l}\text { Use in hu- } \\
\text { man reported }\end{array}$ & $\begin{array}{l}\text { Registration } \\
\text { for mucosal route }(\mathrm{EU})^{\#}\end{array}$ \\
\hline Captopril & ACE-I & s.1. & NO & inactivation & 2 & YES & $\begin{array}{l}\text { NO } \\
\text { Commonly used off label }\end{array}$ \\
\hline $\begin{array}{l}\text { Perindopil } \\
\text { arginine }\end{array}$ & ACE-I & s.1./ODT & YES & activation & $\begin{array}{l}1.2 \\
\text { ( } 30-120 \text { for } \\
\text { Perindoprilat) }\end{array}$ & YES & YES* \\
\hline Nitrendipine & Ca blocker & s.l. & NO & inactivation & 8 & YES & $\begin{array}{l}\text { NO } \\
\text { Documented use off label }\end{array}$ \\
\hline Amlodipine & Ca blocker & s.1./ODT & NO & Slow inactivation & $40-60$ & YES & YES* \\
\hline $\begin{array}{l}\text { Metoprolol } \\
\text { tartrate }\end{array}$ & Beta-blocker & p.r. & NO & inactivation & $3-4$ & YES & NO \\
\hline Propranolol & Beta-blocker & $\begin{array}{l}\text { p.r. } \\
\text { s.l. }\end{array}$ & NO & inactivation & $3-4$ & YES & NO \\
\hline Furosemide & $\begin{array}{l}\text { Loop } \\
\text { diuretic }\end{array}$ & p.r. & NO & inactivation & 2 & $\begin{array}{l}\text { NO } \\
\text { Reported in } \\
\text { this mini-Rev }\end{array}$ & NO \\
\hline
\end{tabular}

s.l. sublingual; p.o. per os; ODT orodispersible tablets; p.r. per rectum

* registered in some countries in EU, available in few, not commercially available in Poland.

\#In UK Ramipril (ACE-I a prodrug converted to its active form ramiprilat with half-life time 9-18 h) available also in Oral Solution. However the low concentration of this solution $(2.5 \mathrm{mg} / 5 \mathrm{~mL})$ makes is not suitable for mucosal delivery ${ }^{82}$. 
even if those drugs have not been approved for a particular route of administration. This type of use of registered and authorized drugs/substances does not require any additional approval in Poland and is not considered as an experimental therapy.

The suppositories were custom-made in a compounding pharmacy from registered and commercially available tablets containing either $50 \mathrm{mg}$ of Metoprolol tartrate (Metocard - Polpharma, PL) or $40 \mathrm{mg}$ of Furosemide (Furosemid - Polpharma, PL). The tablets were powdered in the mortar and suspended in Cacao Butter to form suppositories. Metoprolol suppositories were administered BID while Furosemide QAM. Potassium chloride (20 mEq) was supplemented in oral water-soluble form (Kalium effervescens - Synteza, PL).

This regimen was well tolerated with no adverse effects observed. It allowed satisfactory BP and HR control. The patient reported increased diuresis after administration of Furosemide-containing suppositories. Her plasma potassium level was within normal range. No episodes of syncope or bradycardia were reported. At four subsequent visits after initiation of this regimen good BP and heart rate control was demonstrated: $\mathrm{BP} 140 / 80 \mathrm{mmHg}, \mathrm{HR}$ 80/min, BP 140/80 mmHg, HR 80/min; $125 / 70 \mathrm{mmHg}$, HR 70/min, BP 130/75 mmHg, HR 72/min. She remained under GP care for 1.5 years, while the combination of the transmucosal antihypertensive drugs was used during a total duration of 9 months, during exacerbations of her GI symptoms.

Due to the chronic progressive malabsorption syndrome with underweight (BW $43 \mathrm{~kg}$, BMI $17 \mathrm{~kg} / \mathrm{m}^{2}$ ) and constant microcytic anemia (RBC 4.0x10 $/$ uL (3.9 - 5.2), HGB 9.8 g/dL (12 - 15.5), HCT 33\% (36 - 46), MCV 82.3 fL (83 - 103), MCH 24.4 pg (28 - 34), MCHC 29.7 g/dL (32 - 36) patient was referred to a parenteral nutrition center. She finally accepted this decision after long consideration. After the referral she did not follow up with her GP outpatient clinic.

\section{Areas of controversy}

In the contrast to the well-established sublingual administration of Captopril and Nitrendipine in hypertensive urgencies ${ }^{35,36-4083}$, there are no published data of their long-term administration by this route. Metoprolol tartrate suppositories were tested only on very small group of patients and healthy volunteers for duration of 3 days ${ }^{61}$. There are no published data on their long-term administration by this route. Moreover, there are no published reports of rectal administration of Furosemide in humans. It was only tested in animal models ${ }^{79-81}$. Nevertheless, as we described in our case report, the only feasible alternative for such transmucosal regimen was continuous i.v. drug administration in the hospital, which was refused by our patient. ODT forms of Perindopril and Amlodipine that are registered in EU in are not available in Poland. Moreover, transdermal forms of antihypertensive drugs (such as Clonidine TTS used in the US) are not registered. Therefore, we were forced to use this unorthodox therapy exploiting mucosal delivery of four different antihypertensive drugs.

\section{CONCLUSION}

Mucosal administration systems offer a feasible alternative for long-term administration of antihypertensive drugs. We have described a practical approach leading to a successful control of severe hypertension with four different antihypertensive drugs delivered by the mucosal route (two of them sublingual, other two transrectal). This report illustrates the practicability of such approach in the setting of general medical practice. Three of these four drugs have been used previously in humans by the mucosal route, however, only for short-term treatment of hypertensive urgencies (Captopril s.l. and Nitrendipine s.1.) or in pharmacokinetics studies (Metoprolol tartrate p.r). They were never used for long-term control of blood pressure. We describe the first case of long-term use of those drugs. Moreover, we report the first successful clinical use of rectal delivery of Furosemide in a human.

Beside these 4 drugs used by us, also Propranolol was reported to be used in humans by mucosal route. Moreover, in the EU Perindopril and Amlodipine are registered in the form of orodispersible tablets for mucosal administration. However, unfortunately, they are not commercially available in all EU countries including Poland.

Thus, mucosal administration systems offer a viable alternative for oral and parenteral routes for administration of antihypertensive drugs in the medical general practice; however, before widespread adoption into clinical practice, randomized clinical trials of drugs administered by the transmucosal route are needed to establish longterm effects and safety of this delivery route for chronic hypertension control. If adapted, such approach can bring substantial savings to the health care systems. It will also be better accepted by patients who are reluctant to the parenteral administration of drugs.

\section{Search strategy and selection criteria}

Our research strategy was aimed at evaluating studies for mucosal administration of antihypertensive drugs. The terms "mucosal administration", "rectal administration", "sublingual administration”, "orodispersible tablets", suppositories" and "hypertension", "antihypertensive drugs", as well as "Metoprolol”," Propranolol"," Furosemide", "Captopril", "Nitrendipine", "Perindopril"," Amlodipine" were searched in PubMed (NCBI) and Google Scholar and EMA databases. Scientific articles from 1971 to 2018 were searched. All searches were up to date as of January 2018. The searching results were limited to the drugs reported to be used in humans in mucosal delivery systems at least for pharmacokinetic studies and Furosemide, which use we first report in a practical approach of this mini-review. All language papers were reviewed. All relevant articles were reviewed. The medical team at the General Medical Practice developed the specific medical management protocol.

Acknowledgement: We thank Ewa Borkowska (medical student) for helpful assistance in searching of medical databases. All costs of the publication and manuscript preparation was supported by financial Resources of the 
Private General Practice (Praktyka Lekarska dr n. med. Łukasz Biały NIP:9591228106; REGON:143234827)

Author contributions: All of the authors of this manuscript are responsible for the reported findings. LB collected all clinical data of practical approach and was responsible for the therapeutic process. All authors participated in the searching of the published literature for this review; analysis and interpretation of the data; drafting and/or revising and/or making intellectual contributions to the content of the manuscript; All authors approved the final version of the manuscript submitted for publication.

Conflict of interest statement: The authors state that there are no conflicts of interest regarding the publication of this article.

\section{REFERENCES}

1. Mace AO, McLeod C, Yeoh DK, Vine J, Chen YP, Martin AC, Blyth CC, Bowen AC. Dedicated paediatric Outpatient Parenteral Antimicrobial Therapy medical support: a pre-post observational study. Arch Dis Child 2018;103(2):165-9. doi: 10.1136/archdischild-2017-313071

2. Sangeetha S, Nagasamy Venkatesh D, Krishan P, Saraswathi R. Mucosa as a route for systemic drug delivery. Res J Pharm Biol Chem Sci 2010;1(3):178-87.

3. Hearnden V, Sankar V, Hull K, Juras DV, Greenberg M, Kerr AR, Lockhart PB, Patton LL, Porter S, Thornhill MH. New developments and opportunities in oral mucosal drug delivery for local and systemic disease. Adv Drug Deliv Rev 2012;64(1):16-28.

4. Sattar M, Sayed OM, Lane ME. Oral transmucosal drug delivery--current status and future prospects. Int J Pharm 2014;471(1-2):498-506.

5. Zhang $\mathrm{H}$, Zhang J, Streisand JB. Oral mucosal drug delivery: clinical pharmacokinetics and therapeutic applications. Clin Pharmacokinet 2002;41(9):661-80.

6. Miro A, d'Angelo I, Nappi A, La Manna P, Biondi M, Mayol L, Musto P, Russo R, La Rotonda MI, Ungaro F, Quaglia F. Engineering poly(ethylene oxide) buccal films with cyclodextrin: a novel role for an old excipient? Int J Pharm 2013;452(1-2):283-91.

7. Dey P, Maiti S. Orodispersible tablets: A new trend in drug delivery. J Nat Sci Biol Med 2010;1(1):2-5.

8. Roy A. Orodispersible tablets: a review. Asian J Pharm Clin Res 2016;9:19-26.

9. Fu Y, Yang S, Jeong SH, Kimura S, Park K. Orally fast disintegrating tablets: developments, technologies, taste-masking and clinical studies. Crit Rev Ther Drug Carrier Syst 2004;21(6):433-76.

10. FDA Guidelines https://www.fda.gov/downloads/Drugs/.../ Guidances/ucm070578.pdf.

11. Kaya A, Tatlisu MA, Kaplan Kaya T, Yildirimturk O, Gungor B, Karatas B, Yazici S, Keskin M, Avsar S, Murat A. Sublingual vs. Oral Captopril in Hypertensive Crisis. J Emerg Med 2016;50(1):108-15.

12. Dave S, Shriyan D, Gujjar P. Newer drug delivery systems in anesthesia. J Anaesthesiol Clin Pharmacol 2017;33(2):157-63.

13. Jagdale S, Shewale N, Kuchekar BS. Optimization of Thermoreversible In Situ Nasal Gel of Timolol Maleate. Scientifica (Cairo) 2016;2016:6401267.

14. Jannin V, Lemagnen G, Gueroult P, Larrouture D, Tuleu C. Rectal route in the 21st Century to treat children. Adv Drug Deliv Rev 2014;73:3449

15. Yuan Y, Cui Y, Zhang L, Zhu HP, Guo YS, Zhong B, Hu X, Zhang L, Wang $\mathrm{XH}, \mathrm{Chen} \mathrm{L}$. Thermosensitive and mucoadhesive in situ gel based on poloxamer as new carrier for rectal administration of nimesulide. Int J Pharm 2012;430(1-2):114-9.

16. Jug M, Hafner A, Lovric J, Kregar ML, Pepic I, Vanic Z, Cetina-Cizmek B, Filipovic-Grcic J. An overview of in vitro dissolution/release methods for novel mucosal drug delivery systems. J Pharm Biomed Anal 2018;147:350-366. doi: 10.1016/j.jpba.2017.06.072

17. Nair L, Bhargava HN. Comparison of in vitro dissolution and permeation of fluconazole from different suppository bases. Drug Dev Ind Pharm 1999;25(5):691-4.

18. van Hoogdalem E, de Boer AG, Breimer DD. Pharmacokinetics of rectal drug administration, Part I. General considerations and clinical applications of centrally acting drugs. Clin Pharmacokinet 1991;21(1):11-26.

19. Srikrishna S, Cardozo L. The vagina as a route for drug delivery: a review. Int Urogynecol J 2013;24(4):537-43.

20. Hussain A, Ahsan F. The vagina as a route for systemic drug delivery. J Control Release 2005;103(2):301-13.

21. Mancia G, Fagard R, Narkiewicz K, Redon J, Zanchetti A, Bohm M, Christiaens T, Cifkova R, De Backer G, Dominiczak A, Galderisi M, Grobbee DE, Jaarsma T, Kirchhof P, Kjeldsen SE, Laurent S, Manolis AJ, Nilsson PM, Ruilope LM, Schmieder RE, Sirnes PA, Sleight P, Viigimaa M, Waeber B, Zannad F, Task Force M. 2013 ESH/ESC Guidelines for the management of arterial hypertension: the Task Force for the management of arterial hypertension of the European Society of Hypertension (ESH) and of the European Society of Cardiology (ESC). J Hypertens 2013;31(7):1281-357.

22. Remko $M$, Remková $A$. Perindopril arginin: nová sůl inhibitoru ACE perindoprilu a její př́nos. Remedia 2007;17:421-4.

23. Telejko E. Perindopril arginine: benefits of a new salt of the ACE inhibitor perindopril. Curr Med Res Opin 2007;23(5):953-60.

24. Brunton L, Chabner B, Knollmann B. Goodman \& Gilman's pharmacological basis of therapeutics. New York: McGraw-Hill; 2011.

25. Fox KM, Investigators EUtOrocewPiscAd. Efficacy of perindopril in reduction of cardiovascular events among patients with stable coronary artery disease: randomised, double-blind, placebo-controlled, multicentre trial (the EUROPA study). Lancet 2003;362(9386):782-8.

26. Meurin P. The ASCOT trial: clarifying the role of ACE inhibition in the reduction of cardiovascular events in patients with hypertension. Am J Cardiovasc Drugs 2006;6(5):327-34.

27. Dahlof B, Sever PS, Poulter NR, Wedel H, Beevers DG, Caulfield M, Collins R, Kjeldsen SE, Kristinsson A, Mclnnes GT, Mehlsen J, Nieminen M, O'Brien E, Ostergren J, Investigators A. Prevention of cardiovascular events with an antihypertensive regimen of amlodipine adding perindopril as required versus atenolol adding bendroflumethiazide as required, in the Anglo-Scandinavian Cardiac Outcomes Trial-Blood Pressure Lowering Arm (ASCOT-BPLA): a multicentre randomised controlled trial. Lancet 2005;366(9489):895-906.

28. Patel A, Group AC, MacMahon S, Chalmers J, Neal B, Woodward M, Billot L, Harrap S, Poulter N, Marre M, Cooper M, Glasziou P, Grobbee DE, Hamet P, Heller S, Liu LS, Mancia G, Mogensen CE, Pan CY, Rodgers A, Williams B. Effects of a fixed combination of perindopril and indapamide on macrovascular and microvascular outcomes in patients with type 2 diabetes mellitus (the ADVANCE trial): a randomised controlled trial. Lancet 2007;370(9590):829-40.

29. Beckett NS, Peters R, Fletcher AE, Staessen JA, Liu L, Dumitrascu D, Stoyanovsky V, Antikainen RL, Nikitin Y, Anderson C, Belhani A, Forette F, Rajkumar C, Thijs L, Banya W, Bulpitt CJ, Group HS. Treatment of hypertension in patients 80 years of age or older. $\mathrm{N}$ Engl J Med 2008;358(18):1887-98.

30. Václavík J. Perindopril in the treatment of hypertension and cardiovascular diseases: evolution continues with the orodispersible dosage form. Vnitr Lek 2013;59(4):290-4.

31. Summary of Product Characteristics https://www.drugs.com/uk/ pdf/leaflet/571467.pdf.

32. Glezer On Behalf Of The Optimum Program Participants MG. [Evaluation of Antihypertensive Efficacy and Patient Adherence to Treatment With the New Formulation Perindopril Arginine (Orally Disintegrating Tablet) in General Clinical Practice: OPTIMUM Program]. Kardiologiia 2016;56(4):36-41.

33. Duchin KL, McKinstry DN, Cohen Al, Migdalof BH. Pharmacokinetics of captopril in healthy subjects and in patients with cardiovascular diseases. Clin Pharmacokinet 1988;14(4):241-59.

34. Eichelbaum M, Mikus G, Mast V, Fischer C, Kuhlmann U, Machleidt C. Pharmacokinetics and pharmacodynamics of nitrendipine in healthy subjects and patients with kidney and liver disease. J Cardiovasc Pharmacol 1988;12 Suppl 4:S6-10.

35. Cherney D, Straus S. Management of Patients With Hypertensive Urgencies and Emergencies. J Gen Intern Med 2002;17:937-45.

36. Kazerani H, Hajimoradi B, Amini A, Naseri MH, Moharamzad Y. Clinical efficacy of sublingual captopril in the treatment of hypertensive urgency. Singapore Med J 2009;50(4):400-2.

37. Salkic S, Brkic S, Batic-Mujanovic O, Ljuca F, Karabasic A, Mustafic S. Emergency Room Treatment of Hypertensive Crises. Med Arch 2015;69(5):302-6. 
38. Karakilic E, Buyukcam F, Kocalar G, Gedik S, Atalar E. Same effect of sublingual and oral captopril in hypertensive crisis. Eur Rev Med Pharmacol Sci 2012;16(12):1642-5.

39. Rohr G, Reimnitz P, Blanke P. Treatment of hypertensive emergency. Comparison of a new dosage form of the calcium antagonist nitrendipine with nifedipine capsules. Intensive Care Med 1994;20(4):268 71.

40. Spah F, Grosser K. Treatment of hypertensive urgencies J Cardiovasc Pharmacol 1988;12:154-6.

41. Park JW, Leithauser B, Jung F. Sublingual application of liquid nitrendipine does not result in critical hypotension in healthy volunteers under phosphodiesterase-5 inhibition. Clin Hemorheol Microcirc 2008;39(1-4):323-8.

42. Dabrowski, Szwed. Higher efficacy of oral nitrendipine admininstration in comparison with sublingual route. Nadcisnienie Tetnicze 2005;9:168-77.

43. Abernethy DR. Pharmacokinetics and pharmacodynamics of amlodipine. Cardiology 1992;80 Suppl 1:31-6.

44. van Zwieten PA. Amlodipine: an overview of its pharmacodynamic and pharmacokinetic properties. Clin Cardiol 1994;17(9 Suppl 3):III36.

45. Costanzo P, Perrone-Filardi P, Petretta M, Marciano C, Vassallo E, Gargiulo P, Paolillo S, Petretta A, Chiariello M. Calcium channel blockers and cardiovascular outcomes: a meta-analysis of 175,634 patients. J Hypertens 2009;27(6):1136-51.

46. Julius S, Kjeldsen SE, Weber M, Brunner HR, Ekman S, Hansson L, Hua T, Laragh J, Mclnnes GT, Mitchell L, Plat F, Schork A, Smith B Zanchetti A, group Vt. Outcomes in hypertensive patients at high cardiovascular risk treated with regimens based on valsartan or amlodipine: the VALUE randomised trial. Lancet 2004;363(9426):2022 31.

47. Officers A, Coordinators for the ACRGTA, Lipid-Lowering Treatment to Prevent Heart Attack T. Major outcomes in high-risk hypertensive patients randomized to angiotensin-converting enzyme inhibitor or calcium channel blocker vs diuretic: The Antihypertensive and Lipid-Lowering Treatment to Prevent Heart Attack Trial (ALLHAT) JAMA 2002;288(23):2981-97.

48. Jamerson K, Weber MA, Bakris GL, Dahlof B, Pitt B, Shi V, Hester A Gupte J, Gatlin M, Velazquez EJ, Investigators AT. Benazepril plus amlodipine or hydrochlorothiazide for hypertension in high-risk patients. N Engl J Med 2008;359(23):2417-28.

49. Wright JT, Jr., Bakris G, Greene T, Agodoa LY, Appel LJ, Charleston J, Cheek D, Douglas-Baltimore JG, Gassman J, Glassock R, Hebert L, Jamerson K, Lewis J, Phillips RA, Toto RD, Middleton JP, Rostand SG, African American Study of Kidney D, Hypertension Study G. Effect of blood pressure lowering and antihypertensive drug class on progression of hypertensive kidney disease: results from the AASK trial. JAMA 2002;288(19):2421-31.

50. Sheraz MA, Ahsan SF, Khan MF, Ahmed S, Ahmad I. Formulations of Amlodipine: A Review. J Pharm (Cairo) 2016;2016:8961621.

51. Mohanachandran PS, Krishna Mohan PR, Fels S, Bini KB, Beenu B, SHalina KK. Formulation and evaluation of mouth dispersible tablets of amlodipine besylate. Int J Appl Pharma 2010;2(3):1-6.

52. Bhunia B, Varun j. Formulation and evaluation of orodispers ible tablet of amlodipine besilate. International Journal Of Pharmacy\&Technology 2011;3(4):3745-66.

53 Product Characteristics http://www.mhra.gov.uk/home/groups/par/ documents/websiteresources/con241806.pdf.

54. Mascoli V, Kuruganti U, Bapuji A, Wang R, Damle B. Pharmacokinetics of a Novel Orodispersible Tablet of Amlodipine in Healthy Subjects. J Bioequiv Availab 2013;5:76-9.

55. Liu Y, Jia J, Liu G, Li S, Lu C, Liu Y, Yu C. Pharmacokinetics and bioequivalence evaluation of two formulations of 10-mg amlodipine besylate: an open-label, single-dose, randomized, two-way crossover study in healthy Chinese male volunteers. Clin Ther 2009;31(4):777-83.

56. Jang DJ, Bae SK, Oh E. Coated dextrin microcapsules of amlodipine incorporable into orally disintegrating tablets for geriatric patients. Biomed Pharmacother 2014;68(8):1117-24.

57. Uchida T, Yoshida M, Hazekawa M, Haraguchi T, Furuno H, Teraoka $\mathrm{M}$, Ikezaki $\mathrm{H}$. Evaluation of palatability of 10 commercial amlodipine orally disintegrating tablets by gustatory sensation testing, OD-mate as a new disintegration apparatus and the artificial taste sensor. J Pharm Pharmacol 2013;65(9):1312-20.
58. Blake CM, Kharasch ED, Schwab M, Nagele P. A meta-analysis of CYP2D6 metabolizer phenotype and metoprolol pharmacokinetics. Clin Pharmacol Ther 2013;94(3):394-9.

59. Dollery C. Metoprolol Tartrate. New York: Churchill Livingston; 1999.

60. Abou el Ela Ael S, Allam AA, Ibrahim EH. Pharmacokinetics and antihypertensive effect of metoprolol tartrate rectal delivery system. Drug Deliv 2016;23(1):69-78.

61. de Stoppelaar FM, Stolk LM, Beysens AJ, Stappers JL, Gorgels AP. The relative bioavailability of metoprolol following oral and rectal administration to volunteers and patients. Pharm World Sci 1999;21(5):233-8.

62. Shand DG. Pharmacokinetics of propranolol: a review. Postgrad Med J 1976;52 Suppl 4:22-5.

63. Fitzgerald JD, O'Donnell SR. Pharmacology of 4-hydroxypropranolol, a metabolite of propranolol. Br J Pharmacol 1971;43(1):222-35.

64. Barnwell SG, Laudanski T, Story MJ, Mallinson CB, Harris RJ, Cole SK, Keating M, Attwood D. Improved oral bioavailability of propranolol in healthy human volunteers using a liver bypass drug delivery system containing oleic acid. International Journal of Pharmaceutics 1992;88(1):423-32.

65. Taylan B, Capan Y, Güven O, Kes S, Atilla Hincal A. Design and evaluation of sustained-release and buccal adhesive propranolol hydrochloride tablets. Journal of Controlled Release 1996;38(1):11-20.

66. Ryu J-M, Chung S-J, Lee M-H, Kim C-K, Chang-Koo S. Increased bioavailability of propranolol in rats by retaining thermally gelling liquid suppositories in the rectum. Journal of Controlled Release 1999;59(2):163-72.

67. Sastri MS, Satyanarayana NV, Krishna DR, Diwan PV. In vitro and in vivo studies on slow release propranolol hydrochloride suppositories. Pharmacokinetic and pharmacodynamic evaluation. Arzneimittelforschung 1993;43(3):320-3.

68. Sastry MSP, Satyanarayana NV, Diwan PV, Krishna DR. Formulation, Phafmacokinetic and Pharmacodynamic Evaluation of Fast Releasing Compressed Propranolol. HCL Suppositories. Drug Development and Industrial Pharmacy 1993;19(9):1089-96.

69. Ogiso T, Iwaki M, Kashitani Y, Yamashita K. Enhancement effect of lauric acid on the rectal absorption of propranolol from suppository in rats. Chem Pharm Bull (Tokyo) 1991;39(10):2657-61.

70. Cid E, Mella F, Lucchini L, Carcamo M, Monasterio J. Plasma concentrations and bioavailability of propranolol by oral, rectal, and intravenous administration in man. Biopharm Drug Dispos 1986;7(6):559-66.

71. de Leede LG, Hug CC, Jr., de Lange S, de Boer AG, Breimer DD. Rectal and intravenous propranolol infusion to steady state: kinetics and beta-receptor blockade. Clin Pharmacol Ther 1984;35(2):148-55.

72. May CC, Oyler DR, Parli SE, Talley CL. Rectal propranolol controls paroxysmal sympathetic hyperactivity: a case report. Pharmacotherapy 2015;35(4):e27-31.

73. Basappa VB, Sundaram D, Srinivasan B, Rajamanickam D, Varadharajan M. Design and Evaluation of Sustained Release Propranolol Hydrochloride Suppositories. Int J Pharm Sci Rev Res 2013;22(2):5-12.

74. Chungi VS, Dittert LW, Smith RB. Gastrointestinal sites of furosemide absorption in rats. Int J Pharm 1979;4:27-38.

75. Hammarlund MM, Paalzow LK, Odlind B. Pharmacokinetics of furosemide in man after intravenous and oral administration. Application of moment analysis. Eur J Clin Pharmacol 1984;26(2):197-207.

76. Prandota. Pharmacokinetics and metabolism of furosemide in man. European Journal of Drug Metabolism and Pharmacokinetics 1976;1:177-81.

77. Kim EJ, Han KS, Lee MG. Gastrointestinal first-pass effect of furosemide in rats. J Pharm Pharmacol 2000;52(11):1337-43.

78. Haegeli L, Brunner-La Rocca HP, Wenk M, Pfisterer M, Drewe J, Krahenbuhl S. Sublingual administration of furosemide: new application of an old drug. Br J Clin Pharmacol 2007;64(6):804-9.

79. Berko S, Regdon G, Jr., Ducza E, Falkay G, Eros I. In vitro and in vivo study in rats of rectal suppositories containing furosemide. Eur J Pharm Biopharm 2002;53(3):311-5.

80. Regdon G, Fazekas T, Regdon G, Jr., Selmeczi B. Formulation and in vitro examination of furosemide containing suppositories and preliminary experiences of their clinical use. Pharmazie 1996;51(2):1169

81. Regdon G, Fazekas T, Regdon G, Selmeczi B. [Formulation and in vitro examination of furosemide-containing suppositories and 
preliminary experiences of their clinical use]. Acta Pharm Hung 1997;67(1):19-23.

82. Summary of product characteristics http://www.mhra.gov.uk/home/ groups/spcpil/documents/spcpil/con1510894262379.pdf.

83. Cherney D, Straus S. Management of patients with hypertensive urgencies and emergencies: a systematic review of the literature. J Gen Intern Med 2002;17(12):937-45. 